\title{
PENYULUHAN MANAJEMEN KEUANGAN UNTUK MENINGKATKAN PEREKONOMIAN KELUARGA
}

\author{
${ }^{1}$ Reza Octovian, ${ }^{2}$ Dijan Mardiati, ${ }^{3}$ Hendra Winarsa, ${ }^{4}$ Ali Zaenal Abidin, \\ ${ }^{5}$ Reni Hindriari, ${ }^{5}$ Gunartin \\ Dosen Fakultas Ekonomi Universitas Pamulang \\ ${ }^{6}$ Dosen Fakultas Keguruan Dan Ilmu Pendidikan Universitas Pamulang \\ Email: dosen01431@unpam.ac.id
}

\begin{abstract}
ABSTRAK
Tujuan dari kegiatan pengabdian kepada masyarakat ini adalah untuk menggerakkan masyarakat agar melek mata, sadar bahwa sekarang ini harus cerdas dan bijak dalam manajemen keuangan dengan semakin kompetitif dan sulitnya mendapatkan tambahan penghasilan, maka yang dapat dilakukan yaitu memanajemen keuangan antara pendapatan dan pengeluaran seimbang agar terpenuhi semua kebutuhan keluarga, atau kata peribahasa tidak boleh besar pasak daripada tiangnya.

Metode pengabdian dengan metode seminar, diskusi dan tanya jawab serta evaluasi secara personal.

Hasil kegiatan penyuluhan manajemen keuangan pada Karang Taruna Pamulang Barat, dapat berbagi pengetahuan tentang mengelola keuangan sehingga tidak konsumtif dalam memenuhi kebutuhannya dengan harapan ada kelebihan yang bisa ditabungkan sesuai kemampuannya secara berkelanjutan sehingga aman secara ekonomi.
\end{abstract}

\section{Kata Kunci: Manajemen Keuangan, Perekonomi Keluarga}

\section{PENDAHULUAN}

Manajemen keuangan merupakan seni dan ilmu mengelola uang, atau lebih jelasnya bagaimana cara mendapatkan dana serta secara efektif dan efisien pemanfaatannya untuk memenuhi kebutuhan. Tujuan utama manajemen keuangan untuk memaksimalkan nilai yang dimiliki keluarga atau memberikan nilai tambah terhadap asset yang dimiliki keluarga. Pengetahuan tentang manajemen keuangan dewasa ini sangat penting mengingat dengan perkembangan teknologi dan informasi saai ini cenderung mengkondisikan masyarakat untuk konsumtif.

Sebuah keluarga mampu memenuhi kebutuhan hidupnya bukan karena penghasilan / pendapatannya besar atau warisannya banyak, melainkan bagaimana keluarga tersebut mengelola keuangannya. Keluarga yang mampu mengelola keuangannya dengan efektif dan efisien dan pemenuhan kebutuhan berdasarkan skala prioritas, maka yang demikian itu biasanya lebih baik perekonomi keluarganya, karena pengeluaran keluarga didasarkan besarnya penghasilan yang 
diperolehnya. Perekonomi keluarga juga sangat menentukan tingkat kemampuan pemenuhan kebutuhan anggota keluaga, secara berkelanjutan yang mencerminkan peningkatan perekonomi keluarga. Untuk sampai pada posisi aman dalam ekonomi keluarga perlu upaya terus meningkatkan pendapatan dan mampu memanfaatkannya seefisien mungkin dalam pemenuhan kebutuhan sehingga masih ada kelebihan yang dapat ditabung atau diinvestasikan secara berkelanjutan. Dalam kurun waktu yang lama apabila diakumulasikan maka akan dapat terkumpul dalam jumlah yang besar yang merupakan kekayaan pribadi.

Permasalahnya, tidak semua keluarga mampu mengelola keuangannya dengan baik sehingga terus merasa kurang secara ekonomi. Parahnya lagi apabila sampai minus sehingga harus berhutang untuk memenuhi kebutuhannya. Jika hal ini terjadi berkelanjutan maka tidak saja merasa kekurangan, bahkan merasa tidak aman secara ekonomi keluarga. Maka dari itu penting bagi sebuah keluarga untuk memahami mengelola keuangan atau lebih dikenal dengan istilah manajemen keuangan agar dapat meningkatkan perekonomi keluarga secara berkelanjutan

\section{METODE PELAKSANAAN KEGIATAN}

Metode pelaksanaan dalam kegiatan program pengabdian kepada masyarakat ini dapat dilihat pada gambar berikut:

\section{Gambar 1.1 Metode Pelaksanaan Kegiatan Pengabdian Masyarakat}

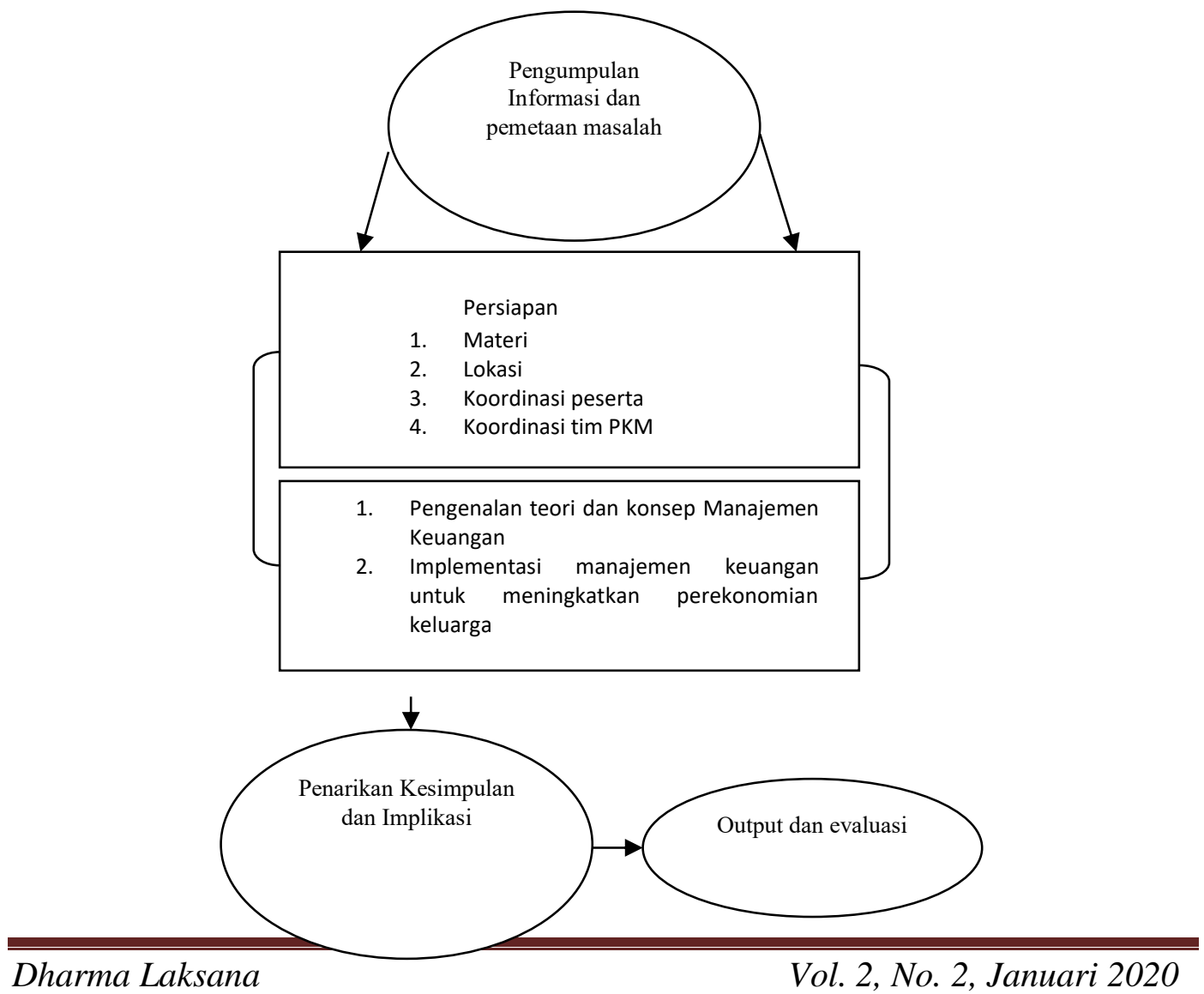




\section{HASIL DAN PEMBAHASAN}

Keluarga merupakan lingkungan terdekat untuk membesarkan, mendewasakan, dan di dalamnya mendapatkan pendidikan pertama kali. Keluarga merupakan lingkungan yang paling kuat dalam membesarkan anak yang belum sekolah. Karena itu keluarga mempunyai peran yang penting dalam perkembangan remaja. Keluarga yang baik akan berpengaruh positif bagi remaja sedangkan keluarga yang kurang baik akan berpengaruh negatif. Oleh karena sejak kecil anak dibesarkan oleh keluarga dan untuk seterusnya sebagian besar waktunya dihabiskan di dalam keluarga.

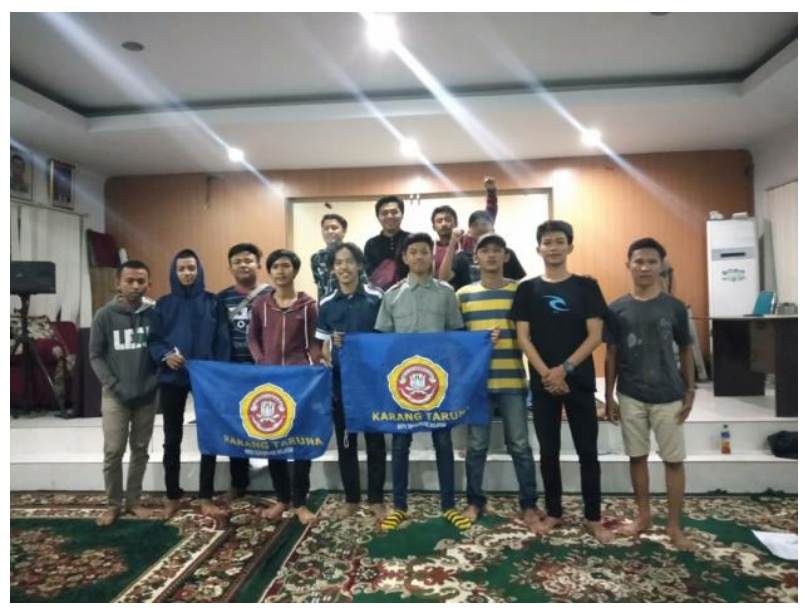

Sebuah keluarga mampu memenuhi kebutuhan hidupnya bukan karena penghasilan atau pendapatannya besar atau warisannya banyak, melainkan bagaimana keluarga tersebut mengelola keuangannya. Keluarga yang mampu mengelola keuangannya dengan efektif dan efisien dan pemenuhan kebutuhan berdasarkan skala prioritas, maka yang demikian itu biasanya lebih baik ekonomi keluarganya, karena pengeluaran keluarga didasarkan besarnya penghasilan yang diperolehnya bukan didasarkan keinginan, dimana sifat dari kebutuhan tidak terbatas sedang sumberdaya ekonomi untuk memenuhi kebutuhan bersifat terbatas (Sukirno, 2016)

Ekonomi keluarga dapat diartikan keadaan atau kedudukan (orang, badan) dalam berhubungan dengan masyarakat di sekelilingnya. Ekonomi berarti urusan keuangan rumah tangga ( organisasi, lembaga) di masyarakat. Ekonomi keluarga juga menentukan tingkat kemampuan pemenuhan kebutuhan anggota keluaga, secara berkelanjutan yang mencerminkan peningkatan ekonomi keluarga (Gunartin, 2019). Untuk sampai pada posisi aman dalam ekonomi keluarga perlu upaya terus meningkatkan pendapatan dan mampu memanfaatkan seefisien mungkin dalam pemenuhan kebutuhan sehingga masih ada kelebihan yang dapat ditabung atau diinvestasikan secara berkelanjutan. Dalam kurun waktu yang lama apabila diakumulasikan maka akan dapat terkumpul dalam jumlah yang besar yang merupakan kekayaan pribadi. 
Kemampuan dalam memajemen keuangan inilah yang menyebabkan perbedaan kondisi ekonomi keluarga, misal si A dan si B sama-sama berpenghasilan Rp. 5.000.000,-. Si A membelanjakan semua penghasilannya untuk memenuhi kebutuhan hidupnya. Sementara si B dengan sedikit hemat mampu menyisihkan penghasilannya Rp. 1.000.000,- setiap bulannya. Hal seperti ini tentu hasil akhirnya akan berbeda. Kondisi ekonomi keluarga yang berbedabeda dalam bermasyarakat mengakibatkan munculnya beberapa lapisan ekonomi yang berbeda dalam masyarakat tersebut, yaitu ekonomi keluarga mampu, ekonomi keluarga sedang dan ekonomi keluarga kurang mampu. Untuk lebih jelasnya pemahaman masing-masing kondisi ekonomi dijabarkan di bawah ini:

a. Ekonomi Keluarga Mampu

Keluarga mampu atau lebih sering dibilang lapisan atas pada masyarakat tertentu juga diistilahkan lapisan elit. Dan biasanya lapisan golongan atas merupakan golongan kecil dalam masyarakat dan juga mengendalikan masyarakat. Kekayaan dapat dijumpai dalam masyarakat ini dan di anggap sebagai hal yang wajar

b. Ekonomi Keluarga Sedang

Status golongan ini dapat hidup di tengah-tengah masyarakat yang bermacam-macam. Golongan ini seseeorang tidak berlebihan di dalam membelanjakan hartanya juga tidak kekurangan di dalam mencukupi kebutuan keluarganya. Status mereka dapat berkomunikasi baik dengan status di atasnya maupun status di bawahnya. Pada tingkatan ini jarang ditemui masalah yang menonjol dalam berkomunikasi dengan status lainnya.

c. Ekonomi Keluarga Kurang Mampu

Status yang kebanyakan melekat pada masyarakat pedesaan atau pemukiman masyarakat yang tertinggal dan berdampak pada kehidupan sehari-hari terutama untuk pendidikan dan mencukupi kebutuhannya.

Peningkatan ekonomi keluarga akan dapat diwujudkan apabila, 1) anggota keluarga memiliki kesadaran yang mendorong pencapaian peningkatan ekonomi; 2) semua anggota keluarga memiliki perilaku jujur, berkomitmen, terbuka, disiplin, bertanggung jawab serta mampu bekerjasama untuk satu tujuan yaitu meningkatkan perekonomian keluarga; 3) memberdayakan kemampuan atau potensi yang dimiliki keluarga dengan harapan dapan meningkatkan pendapatan keluarga; 4) semua anggota keluarga mampu memanfaatkan alokasi sumber ekonomi keluarga berdasarkan kebutuhan bukan keinginan; dan 5) semua anggota keluarga berkomitmen melakukan pengendalian perekonomian keluarga sebaikbaiknya. 
Berdasarkan peran dan fungsi Karang Taruna Kelurahan Pamulang Barat yang banyak membantu dan berkontribusi pada masyarakat, sudah selayaknya dapat perhatian dari semua pihak agar organisasi karang taruna dapat menjalankan peran dan fungsinya secara optimal.

\section{KESIMPULAN DAN SARAN}

Permasalahan yang ada di masyarakat sangat komplek dan variatif, serta tidak sesederhana yang bisa ditangkap oleh mata. Untuk mengetahui permasalahan yang ada dalam masyarakat tentu perlu pendekatan pada masyarakat setempat baru dapat memberikan jalan keluar sebatas yang mampu dilakukan untuk membantu memberikan solusi. Begitu juga dengan Karang Taruna Keluarahan Pamulang Barat, untuk mengembangkan organisasinya tentu tidak hanya butuh pengetahuan tentang manajemen keuangan tetapi juga pengembangan ketrampilan untuk meningkatkan produktifitas sehingga melalui wadah tersebut dapat dikembangkan lagi untuk meningkatkan perekonomi keluarga.

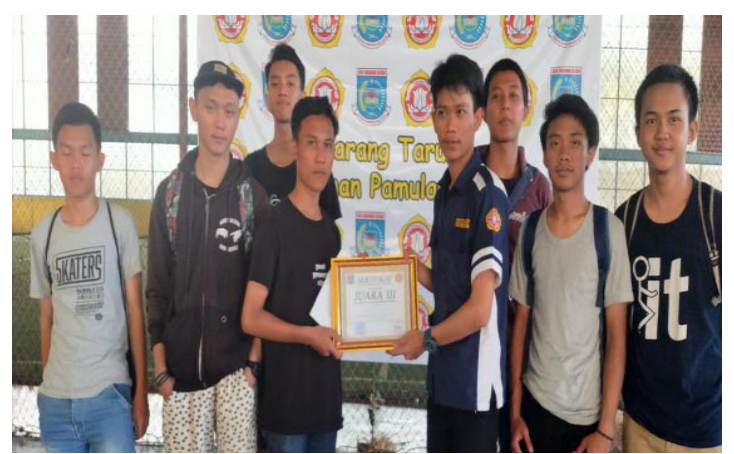

Diharapkan dengan memberikan penyuluhan manajemen keuangan pada Karang Taruna Pamulang Barat, dapat berbagi pengetahuan tentang mengelola keuangan sehingga tidak konsumtif dalam memenuhi kebutuhannya dengan harapan ada kelebihan yang bisa ditabungkan sesuai kemampuannya secara berkelanjutan sehingga aman secara ekonomi. Obyek pada kegiatan pengabdian kepada masyarakat ini adalah Karang Taruna yang terdiri dari pemuda pemudi wilayah Kelurahan Pamulang Barat dimana anggota Karang Taruna merupakan bagian dari masyarakat sebagai penyambung lidah untuk diteruskan kepada keluarganya ataupun masyarakat luas

\section{DAFTAR PUSTAKA}

Gunartin, Soffi, Feb Amni, Pusat Kegiatan Belajar Masyarakat Sebagai Tempat Alternatif Menumbuhkan Kemandirian Wirausaha Warga Belajar (Studi pada PKBM Insan Karya Pamulang Tangerang Selatan, Jurnal PEKOBIS Volume 3 Nomor 2 Oktober 2018

Gunartin, Denok Sunarsi, Syafaatul Hidayati, Peningkatan Ekonomi Keluarga Melalui Pemberdayaan Masyarakat Dengan Membuat Sandal Hias, Jurnal PKM Dharma Laksana Volume 1 Nomor 2 Januari 2019

Sukirno, Sadono. 2016. Ekonomi dan Bisnis. Rajawali Pers. Jakarta. 
Sukirno, Sadono. 2015. Pengantar Teori Mikroekonomi. Raja Grafindo Persada. Jakarta 